\title{
Ontogeny of myeloid cells
}

\author{
Ismé De Kleer ${ }^{1,2,3}$ *, Fabienne Willems ${ }^{4}$, Bart Lambrecht ${ }^{1,2}$ and Stanislas Goriely * \\ ${ }^{1}$ VIB Inflammation Research Center, University of Ghent, Ghent, Belgium \\ ${ }^{2}$ Department of Respiratory Medicine, University Hospital Ghent, Ghent, Belgium \\ ${ }^{3}$ Department of Pulmonary Medicine, Erasmus MC, Rotterdam, Netherlands \\ ${ }_{4}^{4}$ Institute for Medical Immunology (IMI), Université Libre de Bruxelles, Charleroi, Belgium
}

\section{Edited by:}

Tobias R. Kollmann, University of

British Columbia, Canada

\section{Reviewed by:}

Norberto Walter Zwirner, Institute of Biology and Experimental Medicine (IBYME-CONICET), Argentina

Dennis Klinman, NIH, USA

*Correspondence:

Ismé De Kleer, Laboratory of Pulmonary Medicine, Erasmus MC, Wytemaweg 80, Rotterdam 3015CN, Netherlands

e-mail: i.dekleer@erasmusmc.nl, Stanislas Goriely, Institute for Medical Immunology, 8 rue Adrienne Bolland, Charleroi-Gosselies B-6041, Belgium e-mail: stgoriel@ulb.ac.be
Granulocytes, monocytes, macrophages, and dendritic cells (DCs) represent a subgroup of leukocytes, collectively called myeloid cells. During the embryonic development of mammalians, myelopoiesis occurs in a stepwise fashion that begins in the yolk sac and ends up in the bone marrow (BM). During this process, these early monocyte progenitors colonize various organs such as the brain, liver, skin, and lungs and differentiate into resident macrophages that will self-maintain throughout life. DCs are constantly replenished from BM precursors but can also arise from monocytes in inflammatory conditions. In this review, we summarize the different types of myeloid cells and discuss new insights into their early origin and development in mice and humans from fetal to adult life. We specifically focus on the function of monocytes, macrophages, and DCs at these different developmental stages and on the intrinsic and environmental influences that may drive these adaptations.

Keywords: neonate, fetus, dendritic cell, monocyte, macrophage, TLR, cytokine, microbiota

\section{INTRODUCTION}

Granulocytes , monocytes, macrophages, and dendritic cells (DCs) represent a subgroup of leukocytes, collectively called myeloid cells. They circulate through the blood and lymphatic system and are rapidly recruited to sites of tissue damage and infection via various chemokine receptors. Within the tissues they are activated for phagocytosis as well as secretion of inflammatory cytokines, thereby playing major roles in protective immunity. Myeloid cells can also be found in tissues under steady-state conditions, where they control development, homeostasis, and tissue repair.

In this review, we first describe the different types of myeloid cells and their origins in the course of embryogenesis. We then summarize what is known about their functional status in early life and discuss the possible factors that influence their development.

\section{ORIGIN OF MYELOID CELLS EMBRYONIC HEMATOPOIESIS}

Myelopoiesis occurs in mammalians through a stepwise process that begins in the yolk sac (YS) by week 3-4 of gestation in human and on embryonic day 8 (E7) in mice (Figure 1). At this time, long before the generation of definitive hematopoietic stem cells (HSCs), myeloid progenitors develop from the primitive ectoderm of the YS and give rise to embryonic macrophages. This primitive system is followed by definitive hematopoiesis mediated by self-renewing HSCs as the ultimate precursor of the adult hematopoietic hierarchy.

The first HSCs emerging in the embryo derive from the ventral wall of the aorta in the aorta-gonad-mesonephros (AGM) region. At this stage, HSCs can also be found in vitelline/umbilical arteries, the placenta, and YS. Around week 5 of gestation, YS and AGM derived HSCs seed the fetal liver, which is eventually the main fetal hematopoietic site. In the fetal liver, the HSCs expand, mature and, for the first time, give origin to mature erythroid, lymphoid, and myeloid cells $(1,2)$.

Extra-embryonic hematopoiesis ceases around week 10-12 of gestation in human and E12 in mice. The liver remains the predominant hematopoietic site through 20-24 weeks of gestation in human and until birth in mice. From the fetal liver, HSCs colonize the fetal thymus and spleen, niches that support the expansion of HSCs but do not support de novo generation of HSCs. Finally, during the second trimester in human and just before birth in mice the bone marrow (BM) gets colonized, resulting in the production of a small pool of HSCs that are responsible for the maintenance of hematopoiesis throughout adult life (3).

\section{MONOCYTES AND THEIR EARLY DEVELOPMENT}

Monocytes appear in the fetal circulation as soon as self-renewing HSCs have seeded the fetal liver. HSCs develop through various multipotent progenitor stages into monocyte/macrophage and dendritic cell progenitors (MDP). MDP have lost the ability to generate granulocytes and either give rise to "common monocyte progenitors" (cMoPs) restricted to monocytes and their descendants or commit toward a common DC precursor (CDP) $(4,5)$. The transcription factor PU.1 plays a prominent role in monopoiesis at various stages of this commitment. High expression of PU.1 activates myeloid-specific factors such as interferon regulatory factor-8 (IRF8), kruppel-like factor 4 (KLF-4), and Erg1 and at the same time antagonizes key regulators of other developmental pathways, such as GATA-1, GATA-2, and C/EBP $\alpha$. PU.1 is also critical for the expression of the growth factor receptor CD115 (M-CSFR) in MDP as well as during the later stages of differentiation. CD115 and its ligands M-CSF and IL-34 are key regulators of 


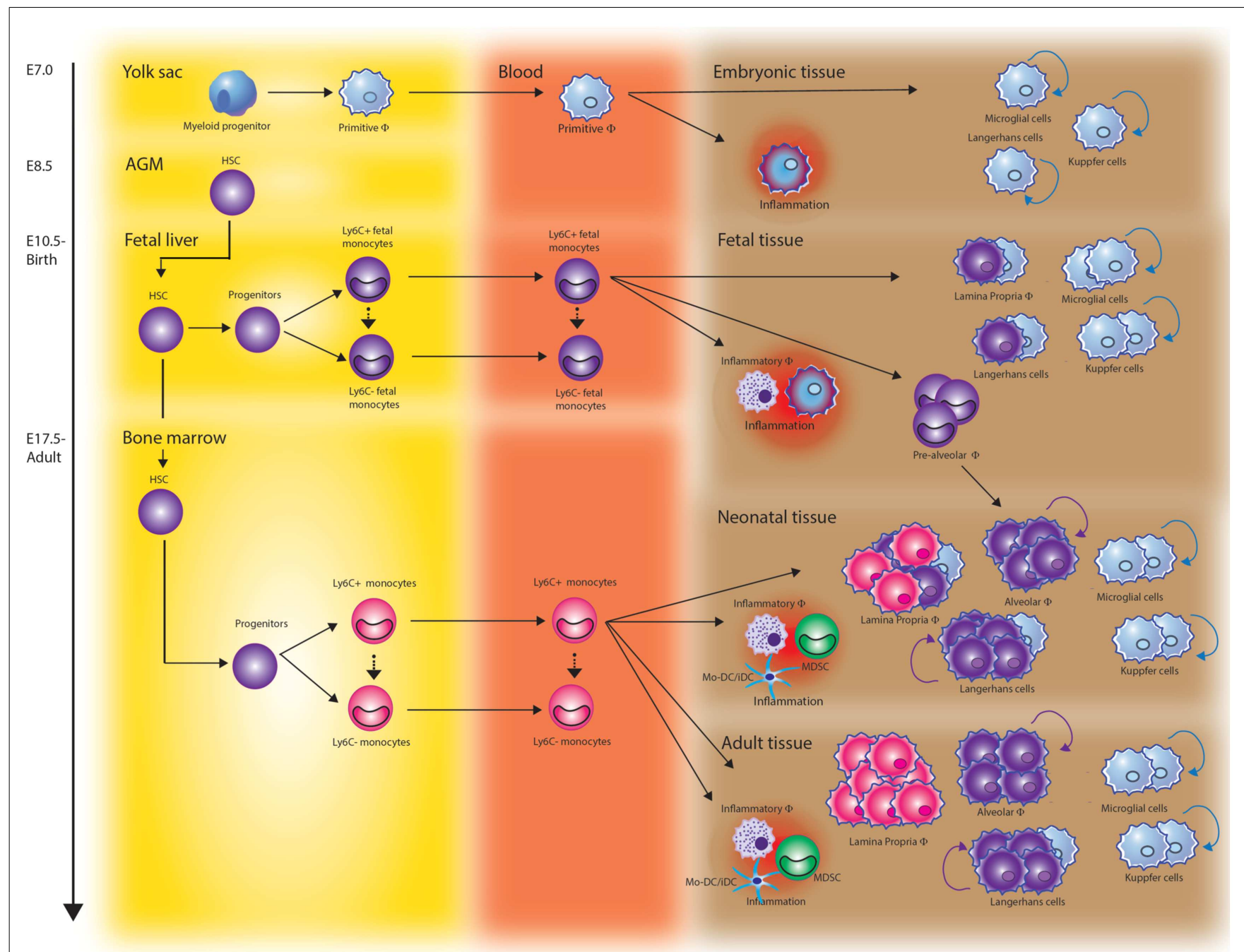

FIGURE 1 |The origin of monocytes and macrophages throughout development. Tissue resident macrophages arise at different stages of development and derive from at least three different sources. During early embryonic development, yolk sac-derived myeloid progenitors give rise to microglia in the brain, Kupffer cells in the liver, and Langerhans cells in the skin. Once fetal liver hematopoiesis has started (E10.5 in mice), fetal liver-derived monocytes differentiate into tissue macrophages and contribute to the Langerhans cell pool in the skin and lamina propria macrophages in the gut. They also seed the lung just before birth. After birth, these cells rapidly differentiate into long-lived alveolar macrophages (AMF) via a "pre-AMF," intermediate differentiation stage. Fetal monocyte-derived Langerhans cells show vigorous proliferation after birth while lamina propria macrophages are continuously renewed via differentiation of bone marrow-derived monocytes. In addition to these resident macrophage populations, Ly6 $C^{\text {high }}$ monocytes can be recruited to sites of infection or injury and differentiate into inflammatory macrophages, monocyte-derived dendritic cells (Mo-DCs), or myeloid-derived suppressor cells (MDSCs). survival, proliferation, and differentiation and indispensable for monocyte development.

Monocytes have long been considered as a developmental intermediate between BM precursors and tissue macrophages. However, renewed interest in recent years has revealed that monocytes carry out specific effector functions during inflammation (6). Monocytes can be divided into two primary subsets based on phenotype and function. The $\mathrm{CD} 14^{++} \mathrm{CD} 16^{-}$classical human monocytes or intermediate $\mathrm{CD} 14^{++} \mathrm{CD} 16^{+}$human monocytes correspond to mouse GR1 ${ }^{+} /$Ly $_{6} \mathrm{C}^{\text {high }}$ inflammatory monocytes and are $\mathrm{CCR} 2^{+} \mathrm{Cx} 3 \mathrm{CR} 1^{\text {low }}$. The non-classical human
$\mathrm{CD} 14^{\mathrm{dim}} \mathrm{CD} 16^{+}$correspond to the $\mathrm{GR} 1^{-} / \mathrm{Ly} 6 \mathrm{C}^{\text {low }}$ mouse monocytes and are CCR2 ${ }^{-}$and express large amounts of Cx3CR1. $\mathrm{GR} 1^{+} /$Ly6 $\mathrm{C}^{\text {high }}$ monocytes and their human $\mathrm{CD} 14^{++} \mathrm{CD} 16^{-}$or $\mathrm{CD} 14^{++} \mathrm{CD} 16^{+}$counterparts are rapidly recruited to sites of infection or injury and have the potential to differentiate into either inflammatory macrophages or monocyte-derived DC (MoDC). They efficiently produce inflammatory mediators such as tumor necrosis factor (TNF) $\alpha$, nitric oxide, and reactive oxygen species. In mice, these cells have shown to be critical for the control of a number of pathogens, including Listeria (7), Mycobacterium $(8,9)$, Cryptococcus (10), Toxoplasma (11), and herpes simplex 
virus (HSV) (12). Human $\mathrm{CD} 14^{\mathrm{dim}} \mathrm{CD} 16^{+}$non-classical monocytes and their mouse Ly6 $6 \mathrm{C}^{\text {low }}$ equivalents patrol blood vessels and mediate early responses against insult (13-16). These cells have also been shown to promote wound healing and angiogenesis in models of atherosclerosis and cardiac infarction.

Although real evidence is still lacking, an accumulating number of studies indicate that monocytes leave the BM as $\mathrm{GR}^{+} /$Ly6 $\mathrm{C}^{\text {high }}$ monocytes and develop via an intermediate stage into $\mathrm{GR} 1^{-} /$Ly6C $^{\text {low }}$ monocytes. However, most of this evidence stems from adult mouse models and differential pathways via distinct precursors during fetal liver hematopoiesis are not excluded. Indeed, a recent study on the human monocytic equivalents suggested that monocytic cells derived from human embryonic stem cells (hESCs) and fetal liver can differentiate from a CD $14^{-} \mathrm{CD} 16^{-}$precursor to form $\mathrm{CD} 14^{++} \mathrm{CD} 16^{+}$cells without producing the $\mathrm{CD} 14^{++} \mathrm{CD}^{-} 6^{-}$cell population that predominates in adult peripheral blood (17). In comparison to adult blood monocytes, the embryonic $\mathrm{CD} 14^{++} \mathrm{CD} 16^{+}$monocytes secreted high amounts of proteins acting on tissue remodeling and angiogenesis and most of them expressed the angiopoietin-1 receptor (Tie2). This suggests that embryonic and fetal monocytic cells may follow a differentiation pathway different to that of adult cells and leading to specific functions. It remains to determine whether these differences reflect the plasticity of a unique cell population generated by the fetal liver environment or reflect the presence of distinct precursors.

\section{THE ORIGIN OF MACROPHAGES: YOLK SAC PROGENITOR OR MONOCYTE?}

Macrophages are resident phagocytic cells in lymphoid and nonlymphoid tissues with highly diverse roles in the maintenance of an organism's biological integrity ranging from development, homeostasis, to repair, and immune responses to pathogens. Macrophages exert these functions through clearance of cell debris, production of growth factors, highly efficient phagocytosis, and the production of inflammatory cytokines. Being equipped with a broad range of pathogen-recognition receptors they can act as sentinels and instantly respond to changes in physiology as well as challenges from outside.

Very recently, the concept of monocytes being precursors of tissue resident macrophages has been challenged and the early origin of tissue macrophages reassessed. Using fate-mapping analysis, it was shown that embryonic macrophages around E8.25, when the embryonic heart starts beating, migrate via the nascent circulation to the central nervous system. Here, they form between E8.5 and E9.5 a stable macrophage compartment, the microglia that maintain them without further input from adult hematopoiesis (18-20). YS macrophages also contribute to other adult tissue macrophage populations including liver Kupffer cells (20). The prototypical macrophages of the skin, epidermal Langerhans cells were shown to have a dual origin involving both YS progenitors and fetal liver-derived monocytes $(21,22)$.

We recently showed that alveolar macrophages (AMF) completely derive from fetal liver-derived monocytes. Although embryonic macrophages colonize the fetal lung around E12.5, we found them quickly outnumbered by high numbers of $\mathrm{GR}^{+} /{ }^{\text {Ly } 6 \mathrm{C}^{\text {high }}}$ fetal liver-derived monocytes entering the lung from E16.5 onward. The fetal liver monocytes differentiate into AMF just after birth and enter the alveolar spaces by 3 days post-natal where they adopt a stable phenotype in response to instructive cytokines and then self-maintain throughout life (23). In contrast to the highly stable macrophage populations in brain and liver and more or less in skin and lungs, the macrophages residing in the intestinal lamina propria are continuously renewed from fetal liver and BM derived GR1 $1^{+} /$Ly6 $\mathrm{C}^{\text {high }}$ monocytes (24).

Thus, tissue resident macrophages arise at different stages of development and from at least three different sources, i.e., YS macrophages and monocytes derived from fetal liver or BM. In addition to these resident macrophage populations that arise under steady-state conditions and at specific time points, $\mathrm{CD} 14^{++} \mathrm{CD} 16^{-}$classical monocytes or their $\mathrm{GR} 1^{+} / \mathrm{Ly}_{6 \mathrm{C}}{ }^{\text {high }}$ counterparts in mice can recruit to sites of infection or injury and differentiate into macrophages.

\section{TROPHIC FUNCTION OF EMBRYONIC MACROPHAGES}

Once the liver becomes a major source of myeloid cells, it becomes difficult to distinguish macrophages of YS and liver origin in the absence of definitive markers. Therefore, most studies to the function of embryonic macrophages have not made distinction between YS derived embryonic macrophages and macrophages that differentiated from fetal liver-derived monocytes. Regardless of their origin, as in adult mice, embryonic macrophages play a key role in innate responses to pathogens and constitute the primary host defense in the mouse embryo. In addition, several lines of evidence suggest important trophic roles for embryonic macrophages $(25,26)$. During early development they are most numerous in areas of active tissue remodeling such as the dorsal midline, the developing retina, and interdigital zone in the developing footpad. Programed cell death is an integral part of embryonic development and the macrophages in these regions are actively involved in phagocytosis of dying cells. Embryonic macrophages are also critically involved in allowing primitive erythropoiesis. They are the major source of the red cell growth factor erythropoietin (27) and ingest the nuclei expelled by maturing erythrocytes (28).

Besides erythropoietin, embryonic macrophages have shown to secrete a wide range of other mediators important for regulation of cell function. For example, embryonic macrophages seem to contribute to vascularization of embryonic tissues by secreting appropriate cytokines, a proposal supported by their close association with the developing vasculature. Furthermore, studies of the optic nerve suggest that macrophages produce factors that are necessary for axon growth and guidance. Embryonic macrophages also have been implicated in depositing components of basement membrane such as proteoglycans, laminin, tiggrin, type IV collagen, and glutactin (29).

Collectively, these data suggest that embryonic macrophages as well as fetal liver-derived monocytes have a major function in tissue growth and remodeling. This conclusion is underscored further by studies showing that the gene signature of mouse embryonic macrophages is shared with the so-called tumorassociated macrophages (TAM) that have tumor remodeling and immunosuppressive functions (30). 


\section{CONVENTIONAL DCs}

Dendritic cells are specialized antigen-processing and -presenting cells. By taking up antigen and bringing it to tissue draining lymphnodes DCs have major functions in the initiation and regulation of adaptive immune responses and are central to the development of immunological memory and tolerance. In recent years, researchers have defined distinct DC subsets differing in surface marker expression and development $(31,32)$. In the adult situation all lymphoid tissue, including spleen, $\mathrm{LN}$, and $\mathrm{BM}$, as well as most non-lymphoid tissue contain two families of conventional DCs in the mouse characterized by either CD $8 \alpha$ and CD103 or CD11b integrin expression and equivalents of human CD141/BDCA $3^{+}$ cDC and CD1c/BDCA1 ${ }^{+}$cDC. $\mathrm{CD} 8 \alpha^{+} \mathrm{cDCs}$ and $\mathrm{CD} 103^{+} \mathrm{cDCs}$ are functionally specialized in cross-presentation of exogenous viral antigen to $\mathrm{CD} 8{ }^{+} \mathrm{T}$ cells $(33,34) . \mathrm{CD} 8 \alpha^{+} \mathrm{cDCs}$ also present glycolipid Ags in CD1d context and can activate and polarize iNKT toward the production of T helper 1 (Th1) or Th2 cytokines (35). Conversely, $\mathrm{CD} 11 \mathrm{~b}^{+}$DCs seem specialized in presenting soluble antigen to CD4 T cells (36) and produce large amounts of proinflammatory chemokines such as CCL3, CCL4, and CCL5 (3739). This specialization of $\mathrm{CD} 1 \mathrm{~b}^{+} \mathrm{cDCs}$ was recently attributed to their expression of the transcription factor IRF4.

In mice, DCs arise from CDPs that expresses the hematopoietic cytokine receptor Flt3 and gives rise to Plasmacytoid DC (pDC) or pre-conventional DCs (pre-cDCs) $(4,40)$. The transcription factors PU.1, Gfil (41), and Cbfb (42) control the development of the common DC lineage. Pre-cDCs can be found in the blood and develop further in the tissue into the two subsets of cDCs. It is unknown whether committed DC progenitors exist in humans. So far, no equivalents of mouse MDP, CDP, or pre-DC have been identified. Development of CD $8 \alpha^{+} \mathrm{cDCs}$ and $\mathrm{CD} 103^{+} \mathrm{cDC}$ from preDCs is orchestrated by the same transcription factors: inhibitor of DNA binding 2 (Id2), IRF8, basic leucine zipper ATF-like 3 transcription factor (BATF3), and the nuclear factor interleukin 3 regulated (NFIL3). CD11 $\mathrm{b}^{+} \mathrm{cDC}$ development is controlled by transcription factors including RelB (43), NOTCH2 (44), RBP-J (45), IRF2 (46), and IRF4 (47).

Conventional DCs generally display a short half-life of approximately 3-6 days and in adults are constantly replenished from BM precursors in a strictly Flt3L-dependent manner (48). So far, splenic DC development has not been investigated during fetal life. At birth, DCs represent only $0.2 \%$ of murine splenic cells and reach adult levels by 3 weeks of age $(49,50)$. A similar post-natal development of DCs is described in murine as well as human neonatal lungs $(51,52)$.

\section{NON-CONVENTIONAL DCs: PLASMACYTOID DCs AND MONOCYTE-DERIVED DCs}

Plasmacytoid DCs are present in the BM and all peripheral organs. They are relatively long-lived and display a characteristic surface phenotype and morphology, including a highly developed secretory compartment (53). pDCs are specialized to respond to viral infection with a massive production of type I interferons (IFNs). They can also act as antigen-presenting cells and control $\mathrm{T}$ cell responses (54-56). Suppression of Id2, the transcription factor critical for cDC development, by E2-2 (also known as TCF4) leads to pDC development $(57,58)$.
As a consequence of inflammation or infection, lymphoid and non-lymphoid organs can also harbor DCs that originate from monocyte infiltrates and have been termed "monocyte-derived DCs" (MoDCs) or "inflammatory DCs" (iDCs) (59-61). For a long-time MoDCs have been phenotypically difficult to discern from cDCs because they share similar expression patterns of MHC-II, CD11b, and CD11c. However, recent studies have identified CD64, the Fc-gamma receptor $1(\mathrm{Fc} \gamma \mathrm{RI})$ as a Mo-DC marker in the mouse $(62,63)$ and indicated that Mo-DCs, through their rapid and numerous recruitment and high production of chemokines and inflammatory cytokines play an important role in the initiation of inflammation $(62,64-66)$.

\section{GRANULOCYTE DEVELOPMENT}

Granulocytes are at all ages the most abundant type of myeloid cells in the blood stream and can be further subdivided into neutrophils, eosinophils, and basophils. All granulocytes derive from the granulocyte/monocyte progenitor (GMP), through further differentiation into the eosinophil lineage-committed progenitor (EoP), and the basophil/mast cell progenitor (BMCP), which in turn gives rise to the mast cell progenitor (MCP) and the basophil progenitor $(\mathrm{BaP})$. With regard to neutrophils a committed progenitor is not yet described. Granulopoiesis is present in the liver parenchyma of human fetuses as early as 5 weeks gestation and is dependent on the transcription factors $\mathrm{C} / \mathrm{EBP} \alpha, \mathrm{PU} .1$, and GATA-2.

In adults, neutrophils are the most frequent granulocytes. They are constantly generated in a high number in the BM and circulate with the blood stream until activated by signals that are provoked by resident macrophages at the site of infection or injury. Once in the tissue neutrophils combat microorganism via phagocytosis, the release of microbicidal proteins and by neutrophil extracellular trap formation. Until the third trimester fetal blood contains few neutrophils. Although mature neutrophils are scarce, progenitor cells with the capacity to generate neutrophil clones are abundant in fetal blood. The production of GM-CSF and G-CSF, the cytokines that drive differentiation of precursors into granulocytes and promote the survival of mature neutrophils is also low in fetal blood. However, G-CSF shows a steep increase just before birth, most likely contributing to the quick rise in neutrophils seen in the same period. This kinetics also fits the finding that G-CSF receptors on the surface of neutrophils of newborn infants are equal in number and affinity to those on adult neutrophils (67).

Eosinophils are resident in various organs such as the gastrointestinal tract and BM and contribute to tissue and immune homeostasis. Only a minor part of the eosinophils circulates in the peripheral blood and is recruited mainly upon $\mathrm{TH} 2$ responses into sites of inflammation. Within the tissues they produce several cytokines and lipid mediators and release toxic granule proteins. Eosinophils are associated with immune responses directed against parasites or allergens and contribute to immune pathology and parasite clearance (68). Eosinophilopoiesis is observed in the fetal liver as early as 5 weeks after gestation. Fetal liver eosinophils still have self-renewing capacity although they already lost the classical stem cell markers (c-Kit, CD34, and Sca-1). The cytokines IL-3, IL-5, and GM-CSF are especially important for eosinophil expansion. Of these three cytokines, IL- 5 is the most specific to the 
eosinophil lineage and is responsible for selective differentiation of eosinophils. Besides neutrophils cord blood contains more mature eosinophils as well as more progenitor cells than adult peripheral blood; thus, neonates seem to have a high capacity to produce high eosinophil counts $(69,70)$. It is also widely known that premature infants develop eosinophilia during the first weeks of post-natal life $(71,72)$. The physiological role of this phenomenon is not yet understood.

The least common granulocytes in the circulation are basophils. Basophils play a central role in inflammatory and immediate allergic reactions. They are able to release potent inflammatory mediators, such as histamine, proteases, chemotactic factors, cytokines, and metabolites of arachidonic acid that act on the vasculature, smooth muscle, connective tissue, mucous glands, and inflammatory cells.

\section{FUNCTIONAL STATUS OF MONOCYTES, INFLAMMATORY DC, AND MACROPHAGES IN EARLY LIFE}

As discussed in the previous sections, the first days/weeks of postnatal life in mice is an important transition period for the ontogeny of monocyte/macrophage system this reflects the sources of progenitors (different waves from the YS, the liver, and the BM), the local production of growth factors and the influence of the first encounter with microorganisms from the microbiota. It is therefore not surprising that the functional capacity of macrophages gradually changes during this period. For example, in young rats, AMF display a lower capacity for phagocytosis and cytokine production (73). Epidermal Langerin ${ }^{+}$cells proliferate intensely during the first week of life (21). These cells display reduced capacity to activate $\mathrm{T}$ cells and low expression of costimulatory molecules (74).

Due to the longer intra-uterine life, post-natal development of myeloid cell populations in humans might be less important in term infants than in rodents. Recently, distinct functional characteristics were identified between human adult and fetal monocytes by comparing the transcriptional and signaling programs of classical monocytes from fetal (18-22 gestational weeks) and adult BM (75). Interestingly, fetal monocytes phosphorylate canonical and non-canonical STATs and respond more strongly to IFN $\gamma$, IL6 , and IL-4 than adult monocytes. Upon stimulation with IFN $\gamma$, fetal monocytes fail to upregulate costimulatory and antigen presentation genes but instead upregulate many genes, which mediate innate pathogen responses (75).

As far as neonatal human macrophages are concerned, they exhibit decreased responsiveness to IFN $\gamma$, which is associated to a marked alteration in Stat1 phosphorylation (76). A decreased phagocytic activity of $E$. coli was detected in neonatal macrophages compared to adult cells, this alteration being even more pronounced in fetuses before 30 weeks of gestation (77).

Most of our understanding on human myeloid cell function in early life arises from in vitro data obtained with cord blood cells. In terms of cytokine production elicited by TLR ligation, human cord blood mononuclear cells have been found to produce less IL- $1 \alpha$, IL-1 $\beta$, TNF $\alpha$, IL-18, and IL-12p70 but equal or greater amounts of IL- 6 or IL- 10 compared with adult cells. Single cell flow cytometry analysis of cytokine production revealed that cord blood monocytes produced less $\mathrm{TNF} \alpha$ but as much or even more IL-12/23p40 and IL-6 in response to TLR2, TLR4 , and TLR7/8 ligands in comparison to adult monocytes (78). Furthermore, TLR-mediated production of innate immune effector molecules such as oxygen radicals is profoundly attenuated in early life (77). These findings show that TLR-mediated responses of human neonatal monocytes are not globally impaired or altered but follow distinct rules from that of control cells from adults. Although previous studies have indicated reduced expression of TLR-4 on cord blood monocytes compared to its expression in adults, other studies have not. A reduced expression of TLR-4 was recently detected on cord blood monocytes as a consequence of a reduced frequency of intermediate $\mathrm{CD} 14^{++} \mathrm{CD} 16^{+}$monocytes in cord blood compared to the frequency in adult blood of such subset characterized by high TLR-4 expression (79). In comparison to classical $\mathrm{CD} 14^{++} \mathrm{CD} 16^{-}$and non-classical $\mathrm{CD} 14^{\mathrm{dim}} \mathrm{CD} 16^{+}$ monocytes, intermediate $\mathrm{CD} 14^{++} \mathrm{CD} 16^{+}$monocytes represent the main producers of $\mathrm{TNF} \alpha$ in response to microbial products. Their reduced frequency in cord blood could therefore contribute to LPS hyporesponsiveness in newborns. At the signaling level, a decreased expression of MYD88, as well as a reduced NF-кBdependent transcriptional activation was observed in neonatal monocytes as compared to adult counterparts (80).

As mentioned earlier, monocytes can differentiate in vivo into iDCs as a consequence of inflammation or infection and in vitro in presence of GM-CSF and IL-4 or by migrating through the endothelium $(81,82)$. Cord blood MoDCs were found to produce very low levels of IL-12p70 in response to LPS, poly I:C, Bordetella pertussis toxin or CD40 ligation (83-85). This limited production of IL-12p70 is due to a specific decrease in the transcription of the IL-12p35 subunit, while the IL-12p40 subunit transcription is preserved. Moreover, expression of IFN $\beta$ and IFN-inducible genes such as CXCL9, CXCL10, and CXCL11 are selectively reduced in LPS-stimulated cord blood cells in comparison to adult cells (86). A low IFN $\beta$ production was associated with a decreased expression of interferon regulatory factor (IRF)3-dependent genes but not of NF-кB-dependent genes, indicating that TRIF-dependent signaling events are preferentially affected in neonatal cells despite comparable levels of TLR-4 expression in adult and neonatal MoDCs. While proximal signals leading to IRF3 activation are preserved, its interaction with CBP are altered in neonatal DCs, leading to impaired DNA binding capacity (86). In addition to its critical role in TLR-4-mediated IFN $\beta$ synthesis, IRF3 is also directly involved in IL-12p35 gene expression (87). Interestingly, reduced IL-12p70 synthesis in neonatal MoDCs was associated with impaired chromatin remodeling in the IL-12p35 promoter region (88). It is therefore possible that limited expression of IL12 p35 subunit in LPS-stimulated neonatal MoDCs could be due to altered recruitment of the IRF3/CBP complex to the IL-12p35 promoter.

The observation that the NF- $\mathrm{B}$-dependent pathway in TLR-4 signaling is intact in neonatal MoDCs is consistent with their ability to produce pro-inflammatory cytokines upon LPS stimulation such as TNF- $\alpha$, IL-6, IL-8, and IL-23, which all depend on NF- $\kappa$ B.

Altogether, these findings highlight the differential signaling pathways underlying distinct and unique patterns of inflammatory responses in neonatal and adult monocytes or MoDCs. How these differences may participate to the high burden of 
infectious diseases in early life is still a matter of debate (89). The high susceptibility to specific pathogens in newborns and infants results from many different factors, including immunological, anatomical, genetic, and environmental factors. It is tempting to speculate that the decreased capacity of circulating monocytes to produce inflammatory cytokines such as TNF- $\alpha$ or IL- $1 \beta$ predisposes premature (and term) newborns to widespread bacterial sepsis. Decreased capacity to produce IL-12p70 is long-lasting and correlates with the susceptibility of young children to disseminated infections with pathogens that require efficient Th1-type responses, such as Mycobacterium tuberculosis, Salmonella, or Burkholderia pseudomallei (89). Furthermore, in comparison to adult controls, antigen-specific IFN- $\gamma$ production was found to be decreased upon vaccination with oral polio or hepatitis B vaccines at birth $(90,91)$. However, BCG vaccination at birth elicits higher IFN $\gamma$ and IL-17 production than when the immunization is achieved at 4 months of age (92). These observations re-enforce the notion that the immune system in early life can be efficiently activated under specific conditions.

\section{FUNCTIONAL STATUS OF CONVENTIONAL AND PLASMACYTOID DENDRITIC CELLS IN EARLY LIFE}

As discussed in the previous sections, development of most myeloid cell populations, including DCs is well advanced in human term infants. The situation is different in newborn mice where the splenic composition of DC subsets varies significantly from the adult. Indeed, at birth, $\mathrm{pDC}$ and $\mathrm{CD} 4{ }^{-} \mathrm{CD} 8 \alpha^{-} \mathrm{cDC}$ are found in the spleen whereas $\mathrm{CD} 8 \alpha^{+}$and $\mathrm{CD} 4^{+} \mathrm{cDC}$ are not present $(49,50)$. The $\mathrm{CD} 4{ }^{+} \mathrm{cDC}$ subset predominates by the age of 3 weeks whereas a significant number of $\mathrm{CD} 8 \alpha^{+} \mathrm{cDC}$ accumulate in the spleen by day 6 after birth. This particular $\mathrm{CDC}$ subpopulation is endowed with a high capacity to produce IL-12. Hence, preferential polarization into Th2 cells observed upon immunization in the first week of life was attributed to the delayed maturation of $\mathrm{CD} 8 \alpha^{+}$ cDCs in the spleen (93). IL-12 levels produced by ex vivo isolated splenic cDC from 7-day-old mice were found to be either similar or reduced in comparison to their adult counterparts $(49,50,94)$. The differences could be due to the mode of stimulation as CpG was used either alone or in combination with cytokines. Whatever the reason for this difference, such a delayed maturation of IL-12p70 production also occurs in humans. Indeed, longitudinal studies using whole blood or peripheral mononuclear cell cultures revealed age-dependent changes in TLR-induced cytokines in CDC in infancy. As observed in MoDCs, cDCs synthesize very low levels of IL-12p70 but much higher levels of IL-23 in comparison to adult cells. After TLR stimulation, production of IL-12p70 is still below adult levels in 12 years old children whereas synthesis of IL-23, IL-6, and IL-10 dominates in term infants (78, 95, 96). Interestingly, production of IL-23, IL-6, and IL-10 declines over the first few years of life, while secretion of pro-inflammatory cytokines TNF $\alpha$ and IL- $1 \beta$ gradually increases with age $(97,98)$. These findings indicate that $\mathrm{cDCs}$ have a reduced ability to produce Th1-supporting cytokines, which corresponds to increased risk of infection with intracellular pathogens such as Listeria monocytogenes, M. tuberculosis, and HSV in early life. Conversely, at birth, human cDCs have an enhanced capacity to promote Th17-type immune responses involved in the defense against extracellular pathogens (99). Interestingly, cord blood naïve $\mathrm{CD}^{+} \mathrm{T}$ cells from preterm and term infants have the potential to develop into Th17 effector cells upon in vitro stimulation under Th17 polarizing conditions (99). Th17 responses can be detected in the peripheral blood and the airways of respiratory syncytial virus (RSV)-infected 1-month-old infants suggesting that the capacity for Th17 development may be acquired quickly after birth (100).

Plasmacytoid DCs have the unique property to sense a variety of viruses by pattern recognition receptors and to secrete very rapidly 10-100 times more IFN (IFN)- $\alpha \beta$ than other immune cells. Despite comparable levels of TLR9 and TLR7 expression in adult and neonatal human pDCs, cord blood pDCs exhibit a strong limitation in their capacity to produce IFN $\alpha \beta$ in response to TLR9 as well as TLR7 ligation, HCMV, or HSV-1 exposure (101). This decreased production is associated with a reduced nuclear translocation of IRF7 (102). In contrast, a recent report indicates that purified cord blood pDCs are responsive to $\mathrm{CpG}$ and a variety of viruses (103). Despite such discrepancy, impaired type I IFNs production was demonstrated both in whole cord blood cultures after stimulation with $\mathrm{CpG}$ or R848 and ex vivo in $\mathrm{pDC}$ from cord blood mononuclear cells infected with RSV, showing that human pDCs are clearly less functional in early life (104). Similarly, in mouse, neonatal pDCs exhibit dampened IFN $\alpha$ and IRF7 translocation during lymphocytic choriomeningitis virus (LCMV) infection, which was correlated with downregulation of E2.2, a master transcription factor regulating pDC development and function (105). The fact that neonatal murine pDCs were found to display an adult-like response capacity when assessed in vitro indicates that the decreased functionality of murine $\mathrm{pDCs}$ is not cell-autonomous but reflects the influence of their local environment (see below). Altogether, these observations suggest that early life pDCs responses are tightly regulated in vivo, which may be beneficial to avoid potentially harmful inflammatory or autoimmune reactions and resulting in increased vulnerability to viral pathogens such as influenza, RSV, HSV-1, or cytomegalovirus (CMV).

\section{POTENTIAL MECHANISMS INVOLVED IN THE POST-NATAL ACOUISITION OF ADULT-LIKE FUNCTION BY MYELOID CELLS}

It is generally believed that there is an inherent immaturity in the myeloid compartment in newborns and young infants that contributes to their susceptibility to infections and impairs their responses to vaccination. As discussed above, this might be the case in rodents where post-natal period is still important for the colonization of lymphoid and non-lymphoid organs by liver and BM myeloid progenitors. In humans, monocytic cells derived from embryonic and fetal liver progenitors preferentially express M2-type signature genes (17). In comparison to their adult counterparts, BM monocytes from mid-gestational age also display distinct responsiveness to cytokine stimulation. These results imply that the functional differences observed in early life could result from a distinct origin of precursors. However, it is not clear when the transition between fetal (liver) versus "adult-like" (BM) myeloid progenitors occurs in human ontogeny. Colonization of BM by hematopoietic progenitors starts around 15-16 weeks of gestation (106). High levels of circulating HSCs are observed 
before 32 weeks of gestation, probably reflecting the active transfer of hematopoiesis from liver to BM (107). Hence, in term newborns, BM probably represents the major source of myeloid progenitors. Yet, at birth, the function of these different subpopulations appears to be qualitatively and quantitatively different from that of adults. The classical model of hematopoiesis is based on a hierarchy of progenitors that progressively lose their developmental potential (108). It is not evident to apply this model to monocyte/macrophage/DC differentiation as data from patients with mutations in GATA-2 or IRF8 reveal the intricate relationship between the various "committed" progenitors that allows the convergence of different paths to the same cell types (109). These concepts allow a high degree of functional plasticity in response to micro-environmental cues throughout the differentiation process. Hence, multiple factors can account for the distinct functional properties of myeloid cells in early life (Figure 2). The maternofetal environment is very specific. High local or systemic levels of immunomodulatory factors such as IL-10, TGF $\beta$, or adenosine can directly affect the function of myeloid cells during fetal life or early post-natal life (110). Several populations with immunosuppressive functions were suggested to participate to materno-fetal tolerance. These include regulatory T cells (Tregs), B cells (Bregs), CD71 ${ }^{+}$ erythroid cells, or myeloid-derived suppressor cells (MDSCs)
(111-114). The most dramatic event that occurs at birth is certainly the initial colonization of the gastrointestinal tract by the microbiota. Strikingly, macrophages isolated from mice treated with antibiotics show reduced expression of IFN-responsive genes, suggesting that signals derived from commensal bacteria influence systemic innate antiviral responses (115). Furthermore, this might implicate tunable chromatin level changes as DCs from germfree or antibiotic-treated mice show reduced $\mathrm{H} 3 \mathrm{~K} 4 \mathrm{me} 3$ deposits at specific inflammatory genes (116). Despite normal NF- $\mathrm{B}$ or IRF3 activation upon TLR stimulation, direct recruitment to promoter regions was reduced, an observation that parallels previous findings in cord blood monocyte-derived DCs. Tonic stimulation by commensals might therefore enable rapid induction of specific defense genes upon infection, a hypothesis that goes along well with the concept of "trained immunity" (117). Such mechanism could account for blunted type I IFN and IL-12 production by cord blood DCs and alterations of STAT signaling pathways in fetal monocytes and macrophages. The way microbial-derived signals influence the function of immune cells even at distant sites is still poorly understood. Soluble factors such as metabolites can clearly play a determinant role in this process. Constant diffusion of low-level microbial products such a TLR or NOD ligands from the gastrointestinal tract to the bloodstream could also drive this

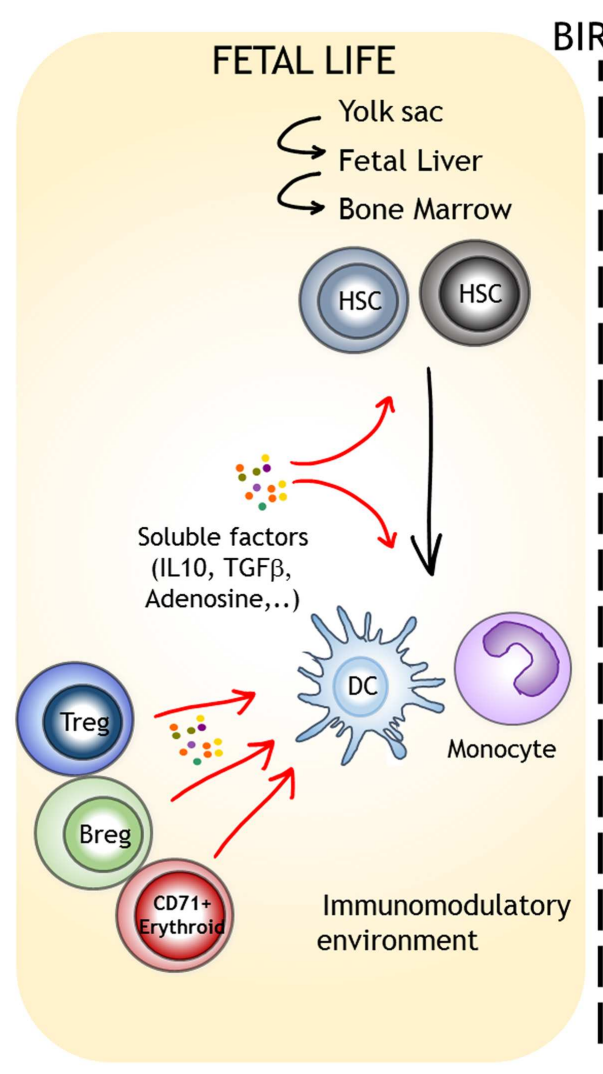

FIGURE 2 | Factors that can account for the different functional properties of monocytes/DCs in the course of their ontogeny. Monocytes and DCs are highly plastic, even in "steady-state" conditions. Lineage specification and function are influences by the origin of the progenitors and by environmental factors. We depict the role of the materno-fetal immunomodulatory environment (red arrows) and the direct or indirect priming effects of microbial-derived signals that are encountered after birth (green arrows). 
bystander control of peripheral responses (118). Interestingly, such mechanisms would then allow the maternal flora to influence the function of fetal innate immune cells during gestation. This systemic effect could, however, be indirect, for example, by triggering the local activation of innate lymphoid cells.

Several reports indicate that the first year of life represents an important period for the acquisition of "adult-like" responsiveness to TLR ligands by circulating monocytes/DCs. Major changes in the composition of the gut and respiratory tract microbiota occur during this period. The development of the microbiota is influenced by multiple factors such as the mode of delivery, the feeding regime, or the use of antibiotics (119). Along this line, decreased diversity of the bacteroidetes phylum in infants born by cesarean section is associated with lower seric levels of CXCL10 and CXCL11, two IFN-dependent chemokines (120). Thus, defined members of the microbiota are likely to influence the trajectory of myeloid cell function in the course of childhood.

In mice, splenic DCs are entirely replaced by circulating progenitors within 2 weeks (121). One would therefore expect the "adjuvant" effect of commensals on myeloid function to be transient and reversible. However, other myeloid subpopulations such as tissue macrophages or Langerhans cells are long-lived and arise from local progenitors. This implies that exposure to other microbial-derived signals, in the context of inter-current infections or vaccination could continuously shape the function of myeloid cells throughout life. Once again, these effects could directly target myeloid cells or influence their function through the activation and expansion of innate lymphocytes such as NK or $\gamma \delta \mathrm{T}$ cells (122-124). The capacity to produce IL-12 slowly increases with age, suggesting that a maturation process occurs throughout life, a phenomenon that parallels the acquisition of memory $\mathrm{T}$ and $\mathrm{B}$ cells.

In conclusion, our knowledge of the origin and development of myeloid cells during embryogenesis and early life has greatly expanded in recent years. The functional capacity of myeloid cells to respond to pathogens is influenced by the origin of their precursors and also by non-cell-autonomous factors such as signals derived from the commensal microbiota. Defining the molecular and cellular mechanisms underlying the determinants of myeloid cell functions in early life will allow a better understanding of the susceptibility of young infants to infections and other clinically relevant implications such as the development of allergies.

\section{ACKNOWLEDGMENTS}

Ismé De Kleer is supported by a VENI grant of the Netherlands Organization Scientific Research (NWO). Stanislas Goriely is a Research fellow from the Fonds National de la Recherche Scientifique (FRS-FNRS, Belgium). This work is supported by an Interuniversity Attraction Pole of the Belgian Federal Science Policy.

\section{REFERENCES}

1. Medvinsky AL, Gan OI, Semenova ML, Samoylina NL. Development of day-8 colony-forming unit-spleen hematopoietic progenitors during early murine embryogenesis: spatial and temporal mapping. Blood (1996) 87:557-66.

2. Kumaravelu P, Hook L, Morrison AM, Ure J, Zhao S, Zuyev S, et al. Quantitative developmental anatomy of definitive haematopoietic stem cells/long-term repopulating units (HSC/RUs): role of the aorta-gonad-mesonephros (AGM) region and the yolk sac in colonisation of the mouse embryonic liver. Development (2002) 129(21):4891-9.

3. Godin I, Cumano A. Of birds and mice: hematopoietic stem cell development. Int J Dev Biol (2005) 49(2-3):251-7.

4. Naik SH, Metcalf D, van Nieuwenhuijze A, Wicks I, Wu L, O'Keeffe M, et al. Intrasplenic steady-state dendritic cell precursors that are distinct from monocytes. Nat Immunol (2006) 7:663-71. doi:10.1038/ni1340

5. Onai N, Obata-Onai A, Schmid MA, Ohteki T, Jarrossay D, Manz MG. Identification of clonogenic common Flt3+M-CSFR+ plasmacytoid and conventional dendritic cell progenitors in mouse bone marrow. Nat Immunol (2007) 8:1207-16. doi:10.1038/ni1518

6. Auffray C, Fogg DK, Narni-Mancinelli E, Senechal B, Trouillet C, Saederup $\mathrm{N}$, et al. CX3CR1+ CD115+ CD135+ common macrophage/DC precursors and the role of CX3CR1 in their response to inflammation. J Exp Med (2009) 206:595-606. doi:10.1084/jem.20081385

7. Serbina NV, Kuziel W, Flavell R, Akira S, Rollins B, Pamer EG. Sequential MyD88-independent and -dependent activation of innate immune responses to intracellular bacterial infection. Immunity (2003) 19:891-901. doi:10.1016/ S1074-7613(03)00330-3

8. Samstein M, Schreiber HA, Leiner IM, Susac B, Glickman MS, Pamer EG. Essential yet limited role for CCR2+ inflammatory monocytes during Mycobacterium tuberculosis-specific T cell priming. Elife (2013) 2:e01086. doi:10.7554/ eLife.01086

9. Peters W, Cyster JG, Mack M, Schlondorff D, Wolf AJ, Ernst JD, et al. CCR2dependent trafficking of F4/80dim macrophages and CD11cdim/intermediate dendritic cells is crucial for T cell recruitment to lungs infected with Mycobacterium tuberculosis. J Immunol (2004) 172:7647-53. doi:10.4049/jimmunol. 172.12.7647

10. Traynor T, Kuziel WA, Toews GB, Huffnagle GB. CCR2 expression determines $\mathrm{T} 1$ versus T2 polarization during pulmonary Cryptococcus neoformans infection. J Immunol (2000) 164:2021-7. doi:10.4049/jimmunol.164.4.2021

11. Dunay I, Fuchs A, Sibley LD. Inflammatory monocytes but not neutrophils are necessary to control infection with Toxoplasma gondii in mice. Infect Immun (2010) 78:1564-70. doi:10.1128/IAI.00472-09

12. Wojtasiak M, Pickett DL, Tate MD, Bedoui S, Job ER, Whitney PG, et al. Gr$1+$ cells, but not neutrophils, limit virus replication and lesion development following flank infection of mice with herpes simplex virus type-1. Virology (2010) 407(1):143-51. doi:10.1016/j.virol.2010.08.001

13. Auffray C, Fogg D, Garfa M, Elain G, Join-Lambert O, Kayal S, et al. Monitoring of blood vessels and tissues by a population of monocytes with patrolling behavior. Science (2007) 317:666-70. doi:10.1126/science.1142883

14. Carlin L, Stamatiades EG, Auffray C, Hanna RN, Glover L, Vizcay-Barrena G, et al. Nr4a1-dependent Ly6C(low) monocytes monitor endothelial cells and orchestrate their disposal. Cell (2013) 153:362-75. doi:10.1016/j.cell.2013.03. 010

15. Nahrendorf M, Swirski FK, Aikawa E, Stangenberg L, Wurdinger T, Figueiredo JL, et al. The healing myocardium sequentially mobilizes two monocyte subsets with divergent and complementary functions. J Exp Med (2007) 204:3037-47. doi:10.1084/jem.20070885

16. Swirski F, Nahrendorf M, Etzrodt M, Wildgruber M, Cortez-Retamozo V, Panizzi P, et al. Identification of splenic reservoir monocytes and their deployment to inflammatory sites. Science (2009) 325:612-6. doi:10.1126/science. 1175202

17. Klimchenko O, Di Stefano A, Geoerger B, Hamidi S, Opolon P, Robert T, et al. Monocytic cells derived from human embryonic stem cells and fetal liver share common differentiation pathways and homeostatic functions. Blood (2011) 117:3065-75. doi:10.1182/blood-2010-07-295246

18. Ginhoux F, Greter M, Leboeuf M, Nandi S, See P, Gokhan S, et al. Fate mapping analysis reveals that adult microglia derive from primitive macrophages. Science (2010) 330:841-5. doi:10.1126/science.1194637

19. Kierdorf K, Erny D, Goldmann T, Sander V, Schulz C, Perdiguero EG, et al. Microglia emerge from erythromyeloid precursors via $\mathrm{Pu}$. 1- and Irf8-dependent pathways. Nat Neurosci (2013) 16:273-80. doi:10.1038/nn. 3318

20. Schulz C, Gomez Perdiguero E, Chorro L, Szabo-Rogers H, Cagnard N, Kierdorf $\mathrm{K}$, et al. A lineage of myeloid cells independent of Myb and hematopoietic stem cells. Science (2012) 209:86-90. doi:10.1126/science.1219179

21. Chorro L, Sarde A, Li M, Woollard KJ, Chambon P, Malissen B, et al. Langerhans cell (LC) proliferation mediates neonatal development, homeostasis, and 
inflammation-associated expansion of the epidermal LC network. J Exp Med (2009) 206:3089-100. doi:10.1084/jem.20091586

22. Hoeffel G, Wang Y, Greter M, See P, Teo P, Malleret B, et al. Adult Langerhans cells derive predominantly from embryonic fetal liver monocytes with a minor contribution of yolk sac-derived macrophages. J Exp Med (2012) 209:1167-81. doi:10.1084/jem.20120340

23. Guilliams M, De Kleer I, Henri S, Post S, Vanhoutte L, De Prijck S, et al. Alveolar macrophages develop from fetal monocytes that differentiate into long-lived cells in the first week of life via GM-CSF. J Exp Med (2013) 210:1977-92. doi:10.1084/jem.20131199

24. Varol C, Vallon-Eberhard A, Elinav E, Aychek T, Shapira Y, Luche H, et al. Intestinal lamina propria dendritic cell subsets have different origin and functions. Immunity (2009) 31:502-12. doi:10.1016/j.immuni.2009.06.025

25. Rae F, Woods K, Sasmono T, Campanale N, Taylor D, Ovchinnikov DA, et al. Characterisation and trophic functions of murine embryonic macrophages based upon the use of a Csflr-EGFP transgene reporter. Dev Biol (2007) 308:232-46. doi:10.1016/j.ydbio.2007.05.027

26. Varol C, Yona S, Jung S. Origins and tissue-context-dependent fates of blood monocytes. Immunol Cell Biol (2009) 87(1):30-8. doi:10.1038/icb.2008.90

27. Gruber D, Zucali JR, Mirand EA. Identification of erythropoietin producing cells in fetal mouse liver cultures. Exp Hematol (1977) 5:392-8.

28. Sasaki K, Sonoda Y, Iwatsuki H, Suda M, Itano C. Death process of primitive erythrocytes and phagocytosis by liver macrophages of the mouse embryo. Kaibogaku Zasshi (1997) 72:123-33.

29. Herbomel P, Thisse B, Thisse C. Ontogeny and behaviour of early macrophages in the zebrafish embryo. Development (1999) 126:3735-45.

30. Pucci F, Venneri MA, Biziato D, Nonis A, Moi D, Sica A, et al. A distinguishing gene signature shared by tumor-infiltrating Tie2-expressing monocytes, blood "resident" monocytes, and embryonic macrophages suggests common functions and developmental relationships. Blood (2009) 114:901-14. doi:10.1182/blood-2009-01-200931

31. Geissmann F, Manz MG, Jung S, Sieweke MH, Merad M, Ley K. Development of monocytes, macrophages, and dendritic cells. Science (2010) 327:656-61. doi:10.1126/science. 1178331

32. Boltjes A, van Wijk F. Human dendritic cell functional specialization in steadystate and inflammation. Front Immunol (2014) 5:131. doi:10.3389/fimmu. 2014.00131

33. Desch AN, Randolph GJ, Murphy K, Gautier EL, Kedl RM, Lahoud MH, et al. $\mathrm{CD} 103+$ pulmonary dendritic cells preferentially acquire and present apoptotic cell-associated antigen. J Exp Med (2011) 2011:1789-97. doi:10.1084/jem. 20110538

34. GeurtsvanKessel CH, Lambrecht BN. Division of labor between dendritic cell subsets of the lung. Mucosal Immunol (2008) 1:442-50. doi:10.1038/mi.2008.39

35. Arora P, Baena A, Yu KO, Saini NK, Kharkwal SS, Goldberg MF, et al. A single subset of dendritic cells controls the cytokine bias of natural killer $\mathrm{T}$ cell responses to diverse glycolipid antigens. Immunity (2014) 40:105-16. doi:10.1016/j.immuni.2013.12.004

36. Dudziak D, Kamphorst AO, Heidkamp GF, Buchholz VR, Trumpfheller C, Yamazaki S, et al. Differential antigen processing by dendritic cell subsets in vivo. Science (2007) 315:107-11. doi:10.1126/science.1136080

37. Beaty SR, Rose CE Jr, Sung SS. Diverse and potent chemokine production by lung CD1 1bhigh dendritic cells in homeostasis and in allergic lung inflammation. J Immunol (2007) 178:1882-95. doi:10.4049/jimmunol.178.3.1882

38. del Rio ML, Rodriguez-Barbosa JI, Kremmer E, Forster R. CD103- and CD103+ bronchial lymph node dendritic cells are specialized in presenting and crosspresenting innocuous antigen to CD4+ and CD8+ T cells. J Immunol (2007) 178:6861-6. doi:10.4049/jimmunol.178.11.6861

39. Proietto AI, O'Keeffe M, Gartlan K, Wright MD, Shortman K, Wu L, et al. Differential production of inflammatory chemokines by murine dendritic cell subsets. Immunobiology (2004) 209:163-72. doi:10.1016/j.imbio.2004.03.002

40. Onai N, Obata-Onai A, Schmid MA, Manz MG. Flt3 in regulation of type I interferon-producing cell and dendritic cell development. Ann N Y Acad Sci (2007) 1106:253-61. doi:10.1196/annals.1392.015

41. Rathinam C, Geffers R, Yucel R, Buer J, Welte K, Moroy T, et al. The transcriptional repressor Gfil controls STAT3-dependent dendritic cell development and function. Immunity (2005) 22:717-28. doi:10.1016/j.immuni.2005.04.007

42. Satpathy AT, Briseno CG, Cai X, Michael DG, Chou C, Hsiung S, et al. Runx1 and Cbfbeta regulate the development of Flt3+ dendritic cell progenitors and restrict myeloproliferative disorder. Blood (2014) 123:2968-77. doi:10.1182/ blood-2013-11-539643

43. Wu L, D'Amico A, Winkel KD, Suter M, Lo D, Shortman K. RelB is essential for the development of myeloid-related CD8alpha- dendritic cells but not of lymphoid-related CD8alpha+ dendritic cells. Immunity (1998) 9:839-47. doi:10.1016/S1074-7613(00)80649-4

44. Lewis KL, Caton ML, Bogunovic M, Greter M, Grajkowska LT, Ng D, et al. Notch2 receptor signaling controls functional differentiation of dendritic cells in the spleen and intestine. Immunity (2011) 35:780-91. doi:10.1016/j.immuni. 2011.08.013

45. Caton ML, Smith-Raska MR, Reizis B. Notch-RBP-J signaling controls the homeostasis of CD8- dendritic cells in the spleen. J Exp Med (2007) 204:1653-64.

46. Ichikawa E, Hida S, Omatsu Y, Shimoyama S, Takahara K, Miyagawa S, et al. Defective development of splenic and epidermal CD4+ dendritic cells in mice deficient for IFN regulatory factor-2. Proc Natl Acad Sci U S A (2004) 101:3909-14.

47. Suzuki S, Honma K, Matsuyama T, Suzuki K, Toriyama K, Akitoyo I, et al. Critical roles of interferon regulatory factor 4 in CD11bhighCD8alpha- dendritic cell development. Proc Natl Acad Sci U S A (2004) 101:8981-6.

48. McKenna HJ, Stocking KL, Miller RE, Brasel K, De Smedt T, Maraskovsky E, et al. Mice lacking flt3 ligand have deficient hematopoiesis affecting hematopoietic progenitor cells, dendritic cells, and natural killer cells. Blood (2000) 95:3489-97.

49. Sun CM, Fiette L, Tanguy M, Leclerc C, Lo-Man R. Ontogeny and innate properties of neonatal dendritic cells. Blood (2003) 102(2):585-91. doi:10.1182/ blood-2002-09-2966

50. Dakic A, Shao QX, D'Amico A, O'Keeffe M, Chen WF, Shortman K, et al. Development of the dendritic cell system during mouse ontogeny. J Immunol (2004) 172(2):1018-27. doi:10.4049/jimmunol.172.2.1018

51. Nelson DJ, McMenamin C, McWilliam AS, Brenan M, Holt PG. Development of the airway intraepithelial dendritic cell network in the rat from class II major histocompatibility (Ia)-negative precursors: differential regulation of Ia expression at different levels of the respiratory tract. J Exp Med (1994) 179(1):203-12. doi:10.1084/jem.179.1.203

52. Tschernig T, Debertin AS, Paulsen F, Kleemann WJ, Pabst R. Dendritic cells in the mucosa of the human trachea are not regularly found in the first year of life. Thorax (2001) 56(6):427-31. doi:10.1136/thorax.56.6.427

53. Reizis B, Bunin A, Ghosh HS, Lewis KL, Sisirak V. Plasmacytoid dendritic cells: recent progress and open questions. Ann Rev Immunol (2011) 29:163-83. doi:10.1146/annurev-immunol-031210-101345

54. Colonna M, Trinchieri G, Liu YJ. Plasmacytoid dendritic cells in immunity. Nat Immunol (2004) 5:1219-26. doi:10.1038/ni1141

55. Corcoran L, Ferrero I, Vremec D, Lucas K, Waithman J, O'Keeffe M, et al. The lymphoid past of mouse plasmacytoid cells and thymic dendritic cells. $J$ Immunol (2003) 170:4926-32. doi:10.4049/jimmunol.170.10.4926

56. de Heer HJ, Hammad H, Soullie T, Hijdra D, Vos N, Willart MA, et al. Essential role of lung plasmacytoid dendritic cells in preventing asthmatic reactions to harmless inhaled antigen. J Exp Med (2004) 200:89-98.

57. Ghosh HS, Cisse B, Bunin A, Lewis KL, Reizis B. Continuous expression of the transcription factor e2-2 maintains the cell fate of mature plasmacytoid dendritic cells. Immunity (2010) 33:905-16. doi:10.1016/j.immuni.2010.11.023

58. Kusunoki T, Sugai M, Katakai T, Omatsu Y, Iyoda T, Inaba K, et al. TH2 dominance and defective development of a CD8+ dendritic cell subset in Id2deficient mice. J Allergy Clin Immunol (2003) 111:136-42. doi:10.1067/mai. 2003.29

59. Mildner A, Yona S, Jung S. A close encounter of the third kind: monocytederived cells. Adv Immunol (2013) 120:69-103. doi:10.1016/B978-0-12417028-5.00003-X

60. Segura E, Amigorena S. Inflammatory dendritic cells in mice and humans. Trends Immunol (2013) 34:440-5. doi:10.1016/j.it.2013.06.001

61. Serbina NV, Salazar-Mather TP, Biron CA, Kuziel WA, Pamer EG. TNF/iNOSproducing dendritic cells mediate innate immune defense against bacterial infection. Immunity (2003) 19:59-70. doi:10.1016/S1074-7613(03)00171-7

62. Plantinga M, Guilliams M, Vanheerswynghels M, Deswarte K, Branco-Madeira F, Toussaint W, et al. Conventional and monocyte-derived CD11b $(+)$ dendritic cells initiate and maintain T helper 2 cell-mediated immunity to house dust mite allergen. Immunity (2013) 38:322-35. doi:10.1016/j.immuni.2012.10.016 
63. Tamoutounour S, Henri S, Lelouard H, de Bovis B, de Haar C, van der Woude CJ, et al. CD64 distinguishes macrophages from dendritic cells in the gut and reveals the Th1-inducing role of mesenteric lymph node macrophages during colitis. Eur J Immunol (2012) 42:3150-66. doi:10.1002/eji.201242847

64. Hohl TM, Rivera A, Lipuma L, Gallegos A, Shi C, Mack M, et al. Inflammatory monocytes facilitate adaptive CD4 T cell responses during respiratory fungal infection. Cell Host Microbe (2009) 6:470-81. doi:10.1016/j.chom.2009.10.007

65. Nakano H, Lin KL, Yanagita M, Charbonneau C, Cook DN, Kakiuchi T, et al. Blood-derived inflammatory dendritic cells in lymph nodes stimulate acute T helper type 1 immune responses. Nat Immunol (2009) 10:394-402. doi:10.1038/ni.1707

66. Wuthrich M, Deepe GS Jr, Klein B. Adaptive immunity to fungi. Ann Rev Immunol (2012) 30:115-48. doi:10.1146/annurev-immunol-020711-074958

67. Ohls RK, Li Y, Abdel-Mageed A, Buchanan G Jr, Mandell L, Christensen RD. Neutrophil pool sizes and granulocyte colony-stimulating factor production in human mid-trimester fetuses. Pediatr Res (1995) 37:806-11. doi:10.1203/00006450-199506000-00022

68. Rothenberg ME, Hogan SP. The eosinophil. Ann Rev Immunol (2006) 24:147-74. doi:10.1146/annurev.immunol.24.021605.090720

69. Roberts RL, Ank BJ, Salusky IB, Stiehm ER. Purification and properties of peritoneal eosinophils from pediatric dialysis patients. J Immunol Methods (1990) 126:205-11. doi:10.1016/0022-1759(90)90152-L

70. Bullock JD, Robertson AF, Bodenbender JG, Kontras SB, Miller CE. Inflammatory response in the neonate re-examined. Pediatrics (1969) 44:58-61.

71. Gibson EL, Vaucher Y, Corrigan JJ Jr. Eosinophilia in premature infants: relationship to weight gain. J Pediatr (1979) 95:99-101. doi:10.1016/S00223476(79)80097-9

72. Bhat AM, Scanlon JW. The pattern of eosinophilia in premature infants. A prospective study in premature infants using the absolute eosinophil count. $J$ Pediatr (1981) 98:612. doi:10.1016/S0022-3476(81)80776-7

73. Bakker JM, Broug-Holub E, Kroes H, van Rees EP, Kraal G, van Iwaarden JF. Functional immaturity of rat alveolar macrophages during postnatal development. Immunology (1998) 94(3):304-9. doi:10.1046/j.1365-2567.1998.00518.x

74. Simpson CC, Woods GM, Muller HK. Impaired CD40-signalling in Langerhans' cells from murine neonatal draining lymph nodes: implications for neonatally induced cutaneous tolerance. Clin Exp Immunol (2003) 132(2):201-8. doi:10.1046/j.1365-2249.2003.02154.x

75. Krow-Lucal ER, Kim CC, Burt TD, McCune JM. Distinct functional programming of human fetal and adult monocytes. Blood (2014) 123(12):1897-904. doi:10.1182/blood-2013-11-536094

76. Marodi L, Goda K, Palicz A, Szabo G. Cytokine receptor signalling in neonatal macrophages: defective STAT-1 phosphorylation in response to stimulation with IFN-gamma. Clin Exp Immunol (2001) 126(3):456-60. doi:10.1046/ j.1365-2249.2001.01693.x

77. Strunk T, Temming P, Gembruch U, Reiss I, Bucsky P, Schultz C. Differential maturation of the innate immune response in human fetuses. Pediatr Res (2004) 56(2):219-26. doi:10.1203/01.PDR.0000132664.66975.79

78. Kollmann TR, Crabtree J, Rein-Weston A, Blimkie D, Thommai F, Wang XY, et al. Neonatal innate TLR-mediated responses are distinct from those of adults. J Immunol (2009) 183(11):7150-60. doi:10.4049/jimmunol.0901481

79. Pedraza-Sanchez S, Hise AG, Ramachandra L, Arechavaleta-Velasco F, King CL. Reduced frequency of a CD14+ CD16+ monocyte subset with high tolllike receptor 4 expression in cord blood compared to adult blood contributes to lipopolysaccharide hyporesponsiveness in newborns. Clin Vaccine Immunol (2013) 20(7):962-71. doi:10.1128/CVI.00609-12

80. Yan SR, Qing G, Byers DM, Stadnyk AW, Al Hertani W, Bortolussi R. Role of MyD88 in diminished tumor necrosis factor alpha production by newborn mononuclear cells in response to lipopolysaccharide. Infect Immun (2004) 72(3):1223-9. doi:10.1128/IAI.72.3.1223-1229.2004

81. Romani N, Reider D, Heuer M, Ebner S, Kampgen E, Eibl B, et al. Generation of mature dendritic cells from human blood. An improved method with special regard to clinical applicability. J Immunol Methods (1996) 196(2):137-51. doi:10.1016/0022-1759(96)00078-6

82. Randolph GJ, Beaulieu S, Lebecque S, Steinman RM, Muller WA. Differentiation of monocytes into dendritic cells in a model of transendothelial trafficking. Science (1998) 282(5388):480-3. doi:10.1126/science.282.5388.480

83. De Wit D, Tonon S, Olislagers V, Goriely S, Boutriaux M, Goldman M, et al. "FOCIS": impaired responses to toll-like receptor 4 and toll-like receptor 3 ligands in human cord blood. J Autoimmun (2003) 3:277-81. doi:10.1016/j. jaut.2003.08.003

84. Goriely S, Vincart B, Stordeur P, Vekemans J, Willems F, Goldman M, et al. Deficient IL-12(p35) gene expression by dendritic cells derived from neonatal monocytes. J Immunol (2001) 166(3):2141-6. doi:10.4049/jimmunol.166. 3.2141

85. Tonon S, Goriely S, Aksoy E, Pradier O, Del Giudice G, Trannoy E, et al. Bordetella pertussis toxin induces the release of inflammatory cytokines and dendritic cell activation in whole blood: impaired responses in human newborns. Eur J Immunol (2002) 32(11):3118-25. doi:10.1002/1521-4141(200211) 32:11<3118::AID-IMMU3118>3.0.CO;2-B

86. Aksoy E, Albarani V, Nguyen M, Laes JF, Ruelle JL, De Wit D, et al. Interferon regulatory factor 3-dependent responses to lipopolysaccharide are selectively blunted in cord blood cells. Blood (2007) 109(7):2887-93.

87. Goriely S, Molle C, Nguyen M, Albarani V, Ouled HN, Lin R, et al. Interferon regulatory factor 3 is involved in toll like receptor(TLR)4- and TLR3-induced IL-12p35 gene activation. Blood (2006) 107(3):1078-84. doi:10.1182/blood2005-06-2416

88. Goriely S, Van Lint C, Dadkhah R, Libin M, De Wit D, Demonte D, et al. A defect in nucleosome remodeling prevents IL-12(p35) gene transcription in neonatal dendritic cells. J Exp Med (2004) 199(7):1011-6. doi:10.1084/jem.20031272

89. Kollmann TR, Levy O, Montgomery RR, Goriely S. Innate immune function by toll-like receptors: distinct responses in newborns and the elderly. Immunity (2012) 37(5):771-83. doi:10.1016/j.immuni.2012.10.014

90. Ota MO, Vekemans J, Schlegel-Haueter SE, Fielding K, Whittle H, Lambert $\mathrm{PH}$, et al. Hepatitis B immunisation induces higher antibody and memory Th2 responses in new-borns than in adults. Vaccine (2004) 22(3-4):511-9. doi:10.1016/j.vaccine.2003.07.020

91. Vekemans J, Ota MO, Wang EC, Kidd M, Borysiewicz LK, Whittle H, et al. $\mathrm{T}$ cell responses to vaccines in infants: defective IFNgamma production after oral polio vaccination. Clin Exp Immunol (2002) 127(3):495-8. doi:10.1046/j. 1365-2249.2002.01788.x

92. Burl S, Adetifa UJ, Cox M, Touray E, Ota MO, Marchant A, et al. Delaying bacillus Calmette-Guerin vaccination from birth to $41 / 2$ months of age reduces postvaccination Th1 and IL-17 responses but leads to comparable mycobacterial responses at 9 months of age. J Immunol (2010) 185(4):2620-8. doi:10.4049/jimmunol.1000552

93. Lee HH, Hoeman CM, Hardaway JC, Guloglu FB, Ellis JS, Jain R, et al. Delayed maturation of an IL-12-producing dendritic cell subset explains the early Th2 bias in neonatal immunity. J Exp Med (2008) 205(10):2269-80. doi:10.1084/jem.20071371

94. Vollstedt S, O’Keeffe M, Odermatt B, Beat R, Glanzmann B, Riesen M, et al. Treatment of neonatal mice with Flt3 ligand leads to changes in dendritic cell subpopulations associated with enhanced IL-12 and IFN-alpha production. Eur J Immunol (2004) 34(7):1849-60. doi:10.1002/eji.200324443

95. Upham JW, Lee PT, Holt BJ, Heaton T, Prescott SL, Sharp MJ, et al. Development of interleukin-12-producing capacity throughout childhood. Infect Immun (2002) 70(12):6583-8. doi:10.1128/IAI.70.12.6583-6588.2002

96. Vanden Eijnden S, Goriely S, De Wit D, Goldman M, Willems F. Preferential production of the IL-12(p40)/IL-23(p19) heterodimer by dendritic cells from human newborns. Eur J Immunol (2006) 36(1):21-6. doi:10.1002/eji. 200535467

97. Corbett NP, Blimkie D, Ho KC, Cai B, Sutherland DP, Kallos A, et al. Ontogeny of toll-like receptor mediated cytokine responses of human blood mononuclear cells. PLoS One (2010) 5(11):e15041. doi:10.1371/journal.pone.0015041

98. Nguyen M, Leuridan E, Zhang T, De Wit D, Willems F, Van Damme P, et al. Acquisition of adult-like TLR4 and TLR9 responses during the first year of life. PLoS One (2010) 5(4):e10407. doi:10.1371/journal.pone.0010407

99. Black A, Bhaumik S, Kirkman RL, Weaver CT, Randolph DA. Developmental regulation of Th17-cell capacity in human neonates. Eur J Immunol (2012) 42(2):311-9. doi:10.1002/eji.201141847

100. Stoppelenburg AJ, de RS, Hennus MP, Bont L, Boes M. Elevated Th17 response in infants undergoing respiratory viral infection. Am J Pathol (2014) 184(5):1274-9. doi:10.1016/j.ajpath.2014.01.033

101. De Wit D, Olislagers V, Goriely S, Vermeulen F, Wagner H, Goldman M, et al. Blood plasmacytoid dendritic cell responses to $\mathrm{CpG}$ oligodeoxynucleotides are impaired in human newborns. Blood (2004) 103(3):1030-2. doi:10.1182/ blood-2003-04-1216 
102. Danis B, George TC, Goriely S, Dutta B, Renneson J, Gatto L, et al. Interferon regulatory factor 7-mediated responses are defective in cord blood plasmacytoid dendritic cells. Eur J Immunol (2008) 38(2):507-17. doi:10.1002/eji. 200737760

103. Zhang X, Lepelley A, Azria E, Lebon P, Roguet G, Schwartz O, et al. Neonatal plasmacytoid dendritic cells ( $\mathrm{pDCs}$ ) display subset variation but can elicit potent anti-viral innate responses. PLoS One (2013) 8(1):e52003. doi:10.1371/ journal.pone.0052003

104. Marr N, Wang TI, Kam SH, Hu YS, Sharma AA, Lam A, et al. Attenuation of respiratory syncytial virus-induced and RIG-I-dependent type I IFN responses in human neonates and very young children. J Immunol (2014) 192(3):948-57. doi:10.4049/jimmunol.1302007

105. Belnoue E, Fontannaz P, Rochat AF, Tougne C, Bergthaler A, Lambert PH, et al. Functional limitations of plasmacytoid dendritic cells limit type I interferon, T cell responses and virus control in early life. PLoS One (2013) 8(12):e85302. doi:10.1371/journal.pone.0085302

106. Hann IM, Bodger MP, Hoffbrand AV. Development of pluripotent hematopoietic progenitor cells in the human fetus. Blood (1983) 62(1):118-23.

107. Clapp DW, Baley JE, Gerson SL. Gestational age-dependent changes in circulating hematopoietic stem cells in newborn infants. J Lab Clin Med (1989) 113(4):422-7.

108. Paul F, Amit I. Plasticity in the transcriptional and epigenetic circuits regulating dendritic cell lineage specification and function. Curr Opin Immunol (2014) 30C:1-8. doi:10.1016/j.coi.2014.04.004

109. Collin M, Bigley V, Haniffa M, Hambleton S. Human dendritic cell deficiency: the missing ID? Nat Rev Immunol (2011) 11(9):575-83. doi:10.1038/nri3046

110. Dowling DJ, Levy O. Ontogeny of early life immunity. Trends Immunol (2014) 35(7):299-310. doi:10.1016/j.it.2014.04.007

111. Elahi S, Ertelt JM, Kinder JM, Jiang TT, Zhang X, Xin L, et al. Immunosuppressive CD71+ erythroid cells compromise neonatal host defence against infection. Nature (2013) 504(7478):158-62. doi:10.1038/nature12675

112. Rieber N, Gille C, Kostlin N, Schafer I, Spring B, Ost M, et al. Neutrophilic myeloid-derived suppressor cells in cord blood modulate innate and adaptive immune responses. Clin Exp Immunol (2013) 174(1):45-52. doi:10.1111/cei. 12143

113. Mold JE, Michaelsson J, Burt TD, Muench MO, Beckerman KP, Busch MP, et al. Maternal alloantigens promote the development of tolerogenic fetal regulatory T cells in utero. Science (2008) 322(5907):1562-5. doi:10.1126/science. 1164511

114. Sun CM, Deriaud E, Leclerc C, Lo-Man R. Upon TLR9 signaling, CD5+ B cells control the IL-12-dependent Th1-priming capacity of neonatal DCs. Immunity (2005) 22(4):467-77. doi:10.1016/j.immuni.2005.02.008

115. Abt MC, Osborne LC, Monticelli LA, Doering TA, Alenghat T, Sonnenberg GF, et al. Commensal bacteria calibrate the activation threshold of innate antiviral immunity. Immunity (2012) 37(1):158-70. doi:10.1016/j.immuni.2012.04.011
116. Ganal SC, Sanos SL, Kallfass C, Oberle K, Johner C, Kirschning C, et al. Priming of natural killer cells by nonmucosal mononuclear phagocytes requires instructive signals from commensal microbiota. Immunity (2012) 37(1):171-86. doi:10.1016/j.immuni.2012.05.020

117. Quintin J, Cheng SC, van der Meer JW, Netea MG. Innate immune memory: towards a better understanding of host defense mechanisms. Curr Opin Immunol (2014) 29C:1-7. doi:10.1016/j.coi.2014.02.006

118. Belkaid Y, Hand TW. Role of the microbiota in immunity and inflammation. Cell (2014) 157(1):121-41. doi:10.1016/j.cell.2014.03.011

119. Fouhy F, Ross RP, Fitzgerald GF, Stanton C, Cotter PD. Composition of the early intestinal microbiota: knowledge, knowledge gaps and the use of highthroughput sequencing to address these gaps. Gut Microbes (2012) 3(3):203-20. doi:10.4161/gmic.20169

120. Jakobsson HE, Abrahamsson TR, Jenmalm MC, Harris K, Quince C, Jernberg C, et al. Decreased gut microbiota diversity, delayed bacteroidetes colonisation and reduced Thl responses in infants delivered by caesarean section. Gut (2014) 63(4):559-66. doi:10.1136/gutjnl-2012-303249

121. Liu K, Victora GD, Schwickert TA, Guermonprez P, Meredith MM, Yao K, et al. In vivo analysis of dendritic cell development and homeostasis. Science (2009) 324(5925):392-7. doi:10.1126/science. 1170540

122. Vermijlen D, Brouwer M, Donner C, Liesnard C, Tackoen M, Van RM, et al. Human cytomegalovirus elicits fetal gammadelta $\mathrm{T}$ cell responses in utero. $J$ Exp Med (2010) 207(4):807-21. doi:10.1084/jem.20090348

123. Wehner R, Dietze K, Bachmann M, Schmitz M. The bidirectional crosstalk between human dendritic cells and natural killer cells. J Innate Immun (2011) 3(3):258-63. doi:10.1159/000323923

124. Brilot F, Strowig T, Munz C. NK cells interactions with dendritic cells shape innate and adaptive immunity. Front Biosci (2008) 13:6443-54. doi:10.2741/ 3165

Conflict of Interest Statement: The authors declare that the research was conducted in the absence of any commercial or financial relationships that could be construed as a potential conflict of interest.

Received: 17 July 2014; accepted: 19 August 2014; published online: 03 September 2014. Citation: De Kleer I, Willems F, Lambrecht B and Goriely S (2014) Ontogeny of myeloid cells. Front. Immunol. 5:423. doi: 10.3389/fimmu.2014.00423

This article was submitted to Immunotherapies and Vaccines, a section of the journal Frontiers in Immunology.

Copyright (C) 2014 De Kleer, Willems, Lambrecht and Goriely. This is an open-access article distributed under the terms of the Creative Commons Attribution License (CC $B Y)$. The use, distribution or reproduction in other forums is permitted, provided the original author(s) or licensor are credited and that the original publication in this journal is cited, in accordance with accepted academic practice. No use, distribution or reproduction is permitted which does not comply with these terms. 